\title{
Triple Helix and the evolution of ecosystems of innovation: the case of Silicon Valley
}

\author{
Josep M. Pique ${ }^{1}$, Jasmina Berbegal-Mirabent ${ }^{2^{*}}$ (1) and Henry Etzkowitz ${ }^{3,4}$
}

\footnotetext{
* Correspondence: jberbegal@uic.es ${ }^{2}$ Department of Economy and Business Organization, Universitat Internacional de Catalunya, $\mathrm{C}$. Immaculada, 22, 08017 Barcelona, Spain

Full list of author information is available at the end of the article
}

\begin{abstract}
Silicon Valley's innovation ecosystem has evolved in the last decade. In this study we aim to understand how and why Silicon Valley evolves by identifying changes on the role played by the Triple Helix Agents. We also aim at identifying if changes in one of the agents trigger evolution of the others. Taking the startup as the unit of analysis and applying a multiple case-study approach, the results are analyzed on the bases of the Triple Helix Model and interpreted in the light of the periods of development of an entrepreneurial venture. Our findings suggest that the role of the Triple Helix agents evolves over time and therefore, so does an innovative ecosystem. Main changes refer to the (1) rise of accelerator programs as a new player in the ecosystem; (2) an early engagement of corporations with startups; (3) the geographical expansion of Silicon Valley, now including San Francisco; (4) an increasing commitment of universities with capital funds; and (5) the rise of micromultinationals due to talent shortage and fierce competition in the area.
\end{abstract}

Keywords: Silicon Valley, Innovation ecosystems, Triple Helix, Evolution, Startup

\section{摘 要}

在过去十年中硅谷的创新生态体系不断发展。在这项研究中，我们旨在通过识别 三螺旋机构所起作用的变化来了解硅谷如何以及为何发展。我们的目的还在于 确认其中一个机构的变化是否会引发其他机构的进化。本文以创业公司为分析 单位,运用多种案例的研究方法,在三螺旋模型的基础上对结果进行分析,并根据 创业企业的发展阶段进行解释。我们的研究结果表明，三螺旋机构的作用随着时 间的推移而发展,创新生态体系也是如此。主要变化在于:(1)加速器计划作为生态 体系中的新参与者兴起; (2)大公司与高技术新创公司 (Start-ups)的早期关联; (3)硅 谷的地理扩张,现在已包括旧金山市; (4)大学越来越多地承诺为资本基金工作; (5) 由于硅谷地区人才短缺和竞争激烈微型跨国公司兴起。

关键词: 硅谷, 创新生态体系, 三螺旋, 演化, 高技术新创公司 


\section{Résumé}

L'écosystème de la Silicon Valley a évolué au cours de la dernière décennie. L'objectif de cet article est d'identifier les changements dans les rôles joués par les agents de la Triple Hélice afin de comprendre comment et pourquoi la Silicon Valley évolue; de même, l'étude cherche à savoir si les changements au niveau de l'un des agents entraînent l'évolution des autres. L'article prend la startup comme unité d'analyse et applique une approche d'étude de cas multiple. Les résultats sont analysés sur la base du modèle de la Triple Hélice et interprétés à la lumière des périodes de développement de l'entreprise. Ils suggèrent que le rôle des agents de la Triple Hélice évolue dans le temps, et qu'il en est de même pour l'écosystème d'innovation. Les changements importants sont en rapport à (1) la montée en puissance des accélérateurs de programmes comme un nouvel acteur de l'écosystème; (2) un engagement à temps des entreprises avec les start-ups, (3) l'expansion géographique de la Silicon Valley, incluant maintenant San Francisco; (4) un engagement croissant des universités avec des capitaux; et (5) la montée des micro-multinationales en raison de la pénurie de talents et de la forte concurrence dans la région.

Mots-clés: Silicon Valley, écosystème d'innovation, Triple Hélice, Evolution, Startup

\section{Resumo}

O ecossistema de inovação do Vale do Silício se desenvolveu na última década. Neste artigo nos propomos entender como e porque o Vale do Silício se desenvolve identificando mudanças no papel assumido pelos atores da Hélice-Tríplice. Nos propomos também a identificar se as mudanças em um dos atores desencadeia a evolução nos demais. Tomando as startups como unidades de análise e aplicando uma abordagem de múltiplos casos de estudo, os resultados são analisados nas bases no modelo de Hélice-Tríplice e interpretados à luz dos períodos de desenvolvimento de uma iniciativa empresarial com perfil inovador. Nossas descobertas sugerem que o papel dos agentes de Hélice-Tríplice evolui ao longo do tempo e, por consequência, evolui também em ecossistema inovativo. Mudanças centrais se referem a (1) ascensão de programas aceleradores como novos agentes no ecossistema; (2) um engajamento precoce de empresas com startups; (3) a expansão geográfica do Vale do Silício, incluindo, agora, São Francisco; (4) um compromisso crescente de universidades com fundos de capital; e (5) ascensão de micro-multinacionais devido carência de talento e concorrência acirrada na área.

Palavras-chave: Vale do Silício, ecossistemas de inovação, Hélice-Tríplice, evolução, startup

\section{Аннотация}

Инновационная экосистема Силиконовой долины менялась в течение последнего десятилетия. В настоящем исследовании мы попытались понять, как и почему развивается Силиконовая долина, охарактеризовав смену ролей агентов Тройной спирали. Мы также поставили задачу определить, оказывают ли влияние изменения одного агента на развитие остальных участников. Проанализировав стартап как самостоятельный объект исследования путем рассмотрения нескольких практических примеров, нами были получены результаты в рамках Теории тройной спирали и интерпретированы в контексте периодичности развития предпринимательского проекта. Наши выводы указывают на то, что роль агентов Тройной спирали (Continued on next page) 
(Continued from previous page)

изменяется с течением времени, равно как и сама инновационная экосистема. Значительные изменения связаны с: 1) запуском программ акселлерации в качестве нового участника экосистемы; 2) сотрудничеством корпораций со стартапами на ранней стадии; 3) географической экспансией Силиконовой долины, которая теперь включает Сан-Франциско; 4) усиливающееся взаимодействие университетов с инвестиционными фондами; 5) рост микро-корпораций по причине недостатка кадров и жесткой конкуренции в регионе.

Ключевые слова: Силиконовая долина, Инновационные экосистемы, Тройная спираль, Эволюция, Стартап

\section{Resumen}

El ecosistema de innovación de Silicon Valley ha evolucionado en la última década. El objectivo de este estudio es el de entender cómo evoluciona ese ecosistema debido a cambios en el papel desempeñado por los agentes de la Triple Hélice, y en particular, cómo los cambios en uno de esos agentes desencadena cambios en los otros. Tomando las start-ups como unidad de análisis y utilizando múltiples estudios de caso, los resultados se analizan en base al Modelo de Triple Hélice y se interpretan a la luz de las etapas de desarrollo de una empresa. Nuestros hallazgos sugieren que el papel de los agentes de la Triple Hélice evoluciona con el tiempo y, por lo tanto, también lo hace el ecosistema innovador. Los principales cambios se refieren a: (1) el aumento de los programas de aceleradoras como un nuevo actor en el ecosistema; (2) un compromiso temprano de las grandes corporaciones con los nuevos emprendedores; (3) la expansión geográfica de Silicon Valley, que ahora incluye la ciudad de San Francisco; (4) un compromiso creciente de las universidades con las empresas de capital de riesgo; y (5) el aumento de las micro-multinacionales debido a la escasez de talento y a la feroz competencia en el área.

Palabras Clave: Silicon Valley, ecosistemas de innovación, Triple Hélice, evolución, nuevas empresas

\section{Multilingual abstract}

Please see Additional file 1 for translation of the abstract into Arabic.

\section{Introduction}

Silicon Valley transcended its Route 128 predecessor as the archetype of innovation ecosystems (Saxenian 1985; Bresnahan et al. 2001). Their origin, success and failure has been widely discussed in numerous studies, becoming a very hotly contested topic in the academic literature and policy debate in recent years (Cheyre et al. 2015; Engel 2015; Katz 2015). An image of Silicon Valley as a highly successful entrepreneurial region is the main reference point for those-mainly governments but also universities and private institutions-wanting to re-create such an ecosystem in their homelands. Even though other innovation ecosystems are trying to catch up-different approaches with divergent results are found, from Singapore to Shenzhen, Chile or Barcelona-Silicon Valley always seems to be one step ahead (Ferrary and Granovetter 2009; Ooms et al. 2015).

While weak-entrepreneurial ecosystems evolve-mainly in response to government incentives, regulations or funds-the evolution of strong-entrepreneurial ecosystems, 
such as Silicon Valley, where government also plays a significant role, and the effects in the startup development process remains, however, underexplored (Etzkowitz and Klofsten 2005). Aiming to fill this gap, this paper analyzes the case of the Silicon Valley Innovation Ecosystem. Two reference points of time are considered: 2008 and 2017. In the recent years Silicon Valley has experienced substantial changes. In 2006 Facebook was opened to everyone at least 13 years old with a valid email address and had 100,000 business pages. Apple launched the first iPhone in 2007 which is considered the start of the digitalization era. By 2009, Dropbox and Airbnb were already operating after being accelerated at YCombinator. That same year, Google Ventures and Uber were funded. In 2012, while Facebook was filling its IPO, San Francisco started to see the benefits of the City of San Francisco's Payroll Tax Exclusion launched in 2011 to redevelop the Central Market Street \& Tenderloin areas when Twitter-that had recently raised $\$ 400 \mathrm{M}$-decided to keep its office in the city. While all these events were taking place, what were Silicon Valley universities, government and industries doing to secure a new wave of successful entrepreneurs?

The approach adopted in this study is not focused on illustrating how much Silicon Valley has grown, but rather on investigating the drivers of this evolution and the effects that these changes have had-and still have-in startup formation and growth. As the population and environment changes, and entrepreneurs and investors gain experience, we expect the triple helix agents to have adjusted their roles. Next, acknowledging that innovative ecosystems evolve-through the changes on the role of the Triple Helix agents-we investigate the motivations for these changes to take place. As such, two research questions drive this research: (1) how has the role of the Tripe Helix agents-university, industry and government-changed during the startup creation process in Silicon Valley during the last 10 years? and (2) why has their role changed?

To understand the recent past requires some appreciation of Silicon Valley's century long gestation in which double helices of university-industry, government-industry and university-government converged to transform an agricultural region. 'Silicon Valley' itself originated as a label to denote the emergence of semi-conductor firms on the Peninsular that had by the 1970's taken on the appurtenances of an industrial cluster. Built upon the technical base of an earlier generation of firms in the micro-wave and radio industries that had arisen through interaction with Stanford University and support from federal government contracts in the early twentieth century, the new industry was built upon the invention of the transistor at Bell Labs in the New York metropolitan area, that was imported to Peninsular, through attraction of one of the inventors to an already strong technical region, who wished to form an independent firm. Shockley semiconductor was the seed from which other firms emerged, whose product in high demand from the army for miniaturized communications equipment, set in motion a wave of technological innovation that resulted in the integrated circuit, the semi-conductor chip that became the core of contemporary Silicon Valley. Semi-conductor chips were the base for more Complex hardware, such as the personal computer and then software; new industries that were then included within the rubric of Silicon Valley. A venture capital firm formation model, originating in Boston's Triple Helix and transferred to the Valley also became the basis of firm-formation in other technology areas, whether arising independently from the original technical base, like biotechnology or intersecting with it as in the case of medical devices. Etzkowitz and Klofsten (2005) applied the firm-formation model 
to geographical regions and identified 4 stages; Etzkowitz (2013a) extended the analysis to Silicon Valley, identifying an additional stage of efflorescence and we suggest an "ultimate" stage in which the Valley morphs from a geographical entity, of whatever shape and extension, to a rubric for an industrial oligopoly of global high-tech firms and their subsidiaries, that includes, Seattle's Amazon as well as Apple, Google and Facebook.

Given that this research aims at answering "how" and "why" questions, we use a qualitative study approach. Specifically, 6 case studies were arranged within a multiple-case design. Following Yin (1984) this approach is suitable when the investigators have little control over events, and the focus is posed on a contemporary phenomenon within a real-life context. Our analysis is grounded in two widely accepted models: the Triple Helix model (Etzkowitz and Leydesdorff 2000) - one of the most referenced models used to characterize an innovation ecosystem-and the general business development model which divides the startup process into four stages (Freeman and Engel 2007): inception, launch, growth and maturity. Rooted in these two frameworks, we identify and map the role played by university, government and industry at each stage. Data come from multiple sources, including reports and secondary data, as well as primary data from interviews with six startups and other key informants. This way it is possible to identify and compare the incentives (for public administration), type and source of investments (for industry) and new programs (for universities) established during the period under analysis. We also consider other demographic data such as population, employment, housing or commute to better understand why and how the ecosystem evolved.

The overall conclusion is that changes in one of the agents, force the others to also evolve. Instead of copying what Silicon Valley does now, we argue that other ecosystems should look at the different stages Silicon Valley has gone through and identify which practices may apply to each innovative ecosystem based on its stage of development. Although in this work we particularize for the case of Silicon Valley, the ultimate goal is to develop a useful tool to be used when evaluating initiatives aimed at fostering innovative environments.

The remainder of the paper is structured as follows. The next section summarizes the theoretical underpinnings that support this work. Next, we describe the methodology followed. Results are then presented and discussed. Concluding remarks are finally outlined.

\section{Theoretical underpinnings The Triple Helix model}

The Triple Helix model (Leydesdorff and Etzkowitz 1996) postulates that in a knowledge-based society the boundaries between public and private sector, science and technology, university and industry are increasingly fading, giving rise to a system of overlapping interactions: (a) industry operates as the center of production; (b) government acts as the source of contractual relations that guarantee stable interaction and exchange; and (c) universities are the source of new knowledge and technology. Moreover, each sphere, while retaining its primary role and identity; "takes the role of the other," for example, universities take the role of industry in supporting start-up creation in incubator and accelerator projects. 
While universities have traditionally been viewed as a support structure for innovation, providing trained persons, research results and knowledge to industry, one of the main differences compared to previous approaches is that the Triple Helix model raised the university to an equivalent status. Thus, unlike previous institutional configurations in which universities had a secondary status or were subordinated to either industry or government, in the Triple Helix model the university emerges as an influential actor and equal partner.

Although the Triple Helix model is sometimes interpreted to depict a rather static scheme, with each actor in their respective corner in lagging European regions (Martin et al. 2018) the overlapping movements between the three spheres-or helixes-indicate a dynamic process leading to different configurations. Each helix has an internal core and an external field space, drawing two parallel dimensions that expand simultaneously (Etzkowitz and Zhou 2007). First, the vertical dimension developed by each helix evolves according to the helixes' mission or strategy. These spheres experience internal changes that are independent with respect to the rest of helixes. Second a horizontal dimension, where spheres form an interactive circulatory system with the others in terms of exchanges of goods, services and functions. The interrelations resulting from these movements provide an innovative environment where knowledge flows in all directions. The Triple Helix model is thus conceived as a spiral pattern of innovation that mirrors the complexity of activities and the multiple reciprocal relationships that take place at different points of the process of knowledge capitalization in the science/technology vector (Etzkowitz and Zhou 2018).

A number of works have used this model. For instance, several studies have centered their analyses on the role played by the different agents in the Triple Helix model (e.g., Daniels et al. 2017), how these roles evolve over time (e.g., Chen and Lin 2017) and the usefulness of intermediate organizations or platforms aimed at supporting and speeding up Triple Helix initiatives (e.g. Johnson 2008; Geoghegan et al. 2015; Chen et al. 2016). Other authors have adopted an entrepreneurial approach to investigate the influence of the Triple Helix agents on entrepreneurial innovations' performance of enterprises (e.g., Guerrero and Urbano 2017), on the birth and death rates of firms (e.g., Kim et al. 2012), as well as its applicability to study the knowledge base of an urban economy (e.g., Deakin and Leydesdorff 2014; Rodrigues and Melo 2013).

While the majority of these studies are conducted in developed countries, there is an increasing number of studies applying this model in low performing countries and regions. While some authors report successful cases (Jauhiainen and Suorsa 2008; Ranga et al. 2008) some others claim that due to poor preconditions, Triple Helix initiatives might fail in such settings (Jensen and Tragardh 2004) if diverging interests are not resolved (Fogelberg and Thorpenberg 2012). In this respect, Pugh (2017) and Saad and Zawdie (2005) converge in signaling that the diversity of regional settings, spaces and cultures need to be acknowledged when assessing university-industry-government interactions.

Some recent applications include the analysis of how differences in formal and informal networks-typically influenced by broader geographical, political, economic and social environments-produce distinctive configurations (Smith and Bagchi-Sen 2010), and how the inclusion of two additional spheres-namely civil society, environment-generate different dynamics of economic exchange, 
technological innovation and institutional control (Leydesdorff and Fritsch 2006; Carayannis et al. 2018).

\section{The entrepreneurial venture: Stages and phases of development}

As a company grows, it evolves, and major changes are often observed in its internal organization. Companies' growth and evolution is determined by financial requirements to be reached before moving to the next financial point. Startups are financed through a series of staged investments (Freeman and Engel 2007). Each stage of investmentalso called milestones-is designed to carry the venture to a higher level of achievement and validation. Staged investments help investors minimize risk while increase the valuation of the firm.

Figure 1 illustrates the evolution of the entrepreneurial venture. This figure assumes a great deal of good luck and much hard work on the part of entrepreneurs and investors alike. The scales for both axes-time and cash flow-vary substantially across industries, business models, and organizational forms. The vertical dashed lines represent notable financial events. Such events drive changes in organizational structure and management activities.

The process starts with a small founding event, at the inception (stage I), which commits the founders' efforts to build a new business organization. During or prior to this moment, startups tend to be organic in structure, leadership resides with the inventors, business plans are developed and resources are gathered. The search of capital occupies a substantial portion of the founders' time. The fund is used to define the concept, build the team, determine the customers, analyze competitors and build prototypes. The period ends when prototype versions of the product or service are sold to customers, generating income.

The next stage is the launching (stage II). This period commences when the company begins to generate revenues from sales. The team grows and focuses on improving the product/service based on customers' feedback. At this point, startups seek for their first round of institutional investment at this point. With the venture capitalist investment, organizational routines are developed and formalized, a board of directors is created, and an experienced management team is hired. All these events lead to a dilutive effect

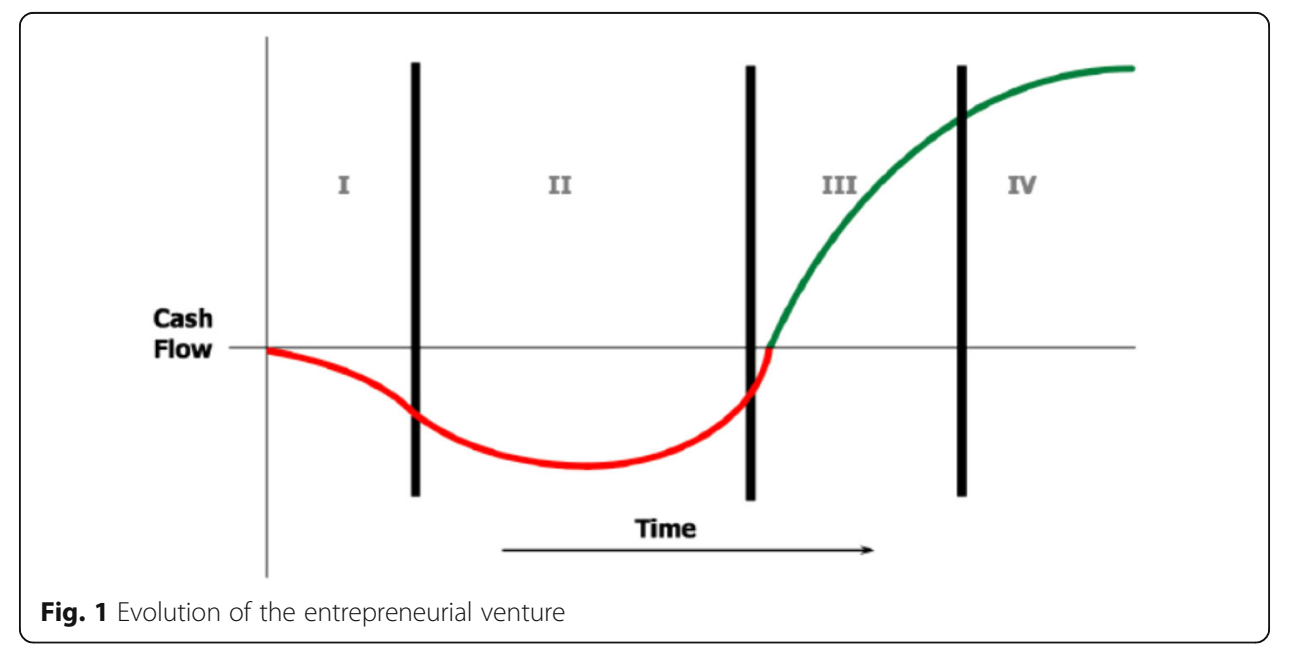


on the equity position of the founders, often reluctant to loss control and shift from creativity to discipline. With continued success, product designs are finalized, marketing and sales efforts expanded and business systems developed. As this process accelerates, cash flows turn positive at the very end of this period.

The growth stage (or building system) follows (stage III). Once the scalability of the product is validated, at this stage the company is able to successfully compete with older rivals. This period is characterized by structural development, managerial skill expansion, organizational routines and roles, and the building of stable relations with suppliers and customers while growing the resources. Access to capital is required to fuel continued rapid growth, and to be ready to scale to large size.

Lastly, in the maturity or corporate management (stage IV) institutional investors usually want to get their money- including their returns on the successful investment-out. Often the exit strategy consists of one major exit event such as an Initial Public Offering (IPO) or a merger and acquisition (M\&A) where the company is acquired. At this time, the full weight of financial regulation and fiduciary responsibility falls on the board and officers of the company.

The above is an ideal-typical model of Silicon Valley firm formation that has been deformed in various ways. For example, large scale funding and rapid expansion may come before successful prototype completion in the race to achieve "network effects" and dominate a market. In software, this may result in release of highly "buggy" products, that are expected to be improved before customer feedback becomes too negative. It may also lead to the announcement of "vaporware" or products that are never sufficiently completed to be released. The worst case are fake and even fraudulent products that have serious negative consequences for users, with the firm and its founders, as in the Theranos instance, becoming subject to investigation, bankruptcy, irreparable reputational damage and possible prison terms (Carreyrou 2018). Even when the venture capital model does not result in dire consequences, a range of middle ground questionable business practices in iconic firms, like Facebook and Uber, have been identified, that are making these firms subject to increased scrutiny and calls for regulation. Nevertheless, the 'capture market share above all else' "Unicorn" fast growth model remains a highly publicized cultural ideal even as a broader reality of "boot-strapped" modest growth firms, avoiding venture capital investment, persists as well in niche areas.

What has changed is the emergence of a super-elite of firms that have generated extraordinary amounts of cash that allow them to buy out any possible competitors. Apple, Amazon, Google and Facebook are the early twenty-first century equivalent of the late nineteenth century "trusts" that dominated the industrial and political landscape of that era, resulting in President McKinley's creation of an "Industrial Commission" (1898-1902) to investigate the phenomenon and recommend remedies (Samuels 1998).

\section{Methodology}

For the purpose of this study, the scope of the analysis is limited to show the trends and changes of the IT sector. Biotech and MedTech companies were discarded since its development process and necessities are specific and different from other sectors. 
Although hardware companies were not initially excluded, none was included in the analysis and therefore we will not consider our results applicable to hardware startups. Given the nature of the two research questions, data were gathered from different sources as described below.

Data referring to 2008 was obtained from the doctoral dissertation of del-Palacio (2009), who interviewed several start-up companies and conducted a detailed analysis of the innovation ecosystem at Silicon Valley. In order to obtain data from 2017 we followed the same procedure as the one employed in del-Palacio (2009),

Accordingly, six in-depth personal interviews with high-position founders or managers of startups were conducted in order to identify the support of and relationship established with universities, industries and government at each stage of business development. Table 1 shows the main characteristics of the six startups. The list of interviewees was based on recommendations and connections. Interviews were very useful because they directly target the case-study topics and focus on causal inference (Yin 1984). In addition, discussions with Silicon Valley entrepreneurs and innovation managers, held in the 2017 Stanford STS 186 Seminar on Triple Helix Innovation and Entrepreneurship, were drawn upon, for example, with the director of the Stanford Research Park.

The interviews comprised in-person conversations and phone calls ranging from 40 to 90 min that were structured as follows. First, we started the interview by summarizing the goals of the study. Second, we asked the interviewees to introduce themselves and to give a short explanation of their company and technology. A template was designed to gather all this data together for each of the startups under analysis (see Fig. 2). The third and most important part of the interview was the collection of the data needed for answering the research questions. This last part was conducted through direct questions about the team, the technology, the location and the go-to-market strategy in each of the stages of the business development cycle (see Fig. 3). Finally, interviewees were asked about their perceptions about the evolution of the Silicon Valley for the past 10 years.

The interviews took place between March and July 2017. All interviews were also recorded to ensure a more accurate attention to the interviewee and the conversation. As shown in both figures, data collected were analyzed on the basis of the Triple Helix model and the lifecycle model of business development.

According to Yin (1984), key informants are often considered critical for the success of a case study. Thus, as a part of the research, ten additional interviews with key informants were conducted during the same period. These interviews were open-ended. The informants (see Table 2) were asked about the facts of the matter allowing them to elaborate on his/her own insights into certain occurrences.

In order to triangulate data, a number of secondary documents were selected and reviewed dealing with the incentives (for public administration), type and source of investments (for industry) and new programs (for universities) established after 2008. The ultimate purpose was to identify some hints on the changes occurred, while allowing us to corroborate or contradict the findings from the interviews. Additional information concerning population, employment, housing or commute was also collected to better understand the changes.

Lastly, in order to analyze the changes in the role of each agent in each stage of business development, we compared the results with those in del-Palacio (2009) referring to year 2008 . 


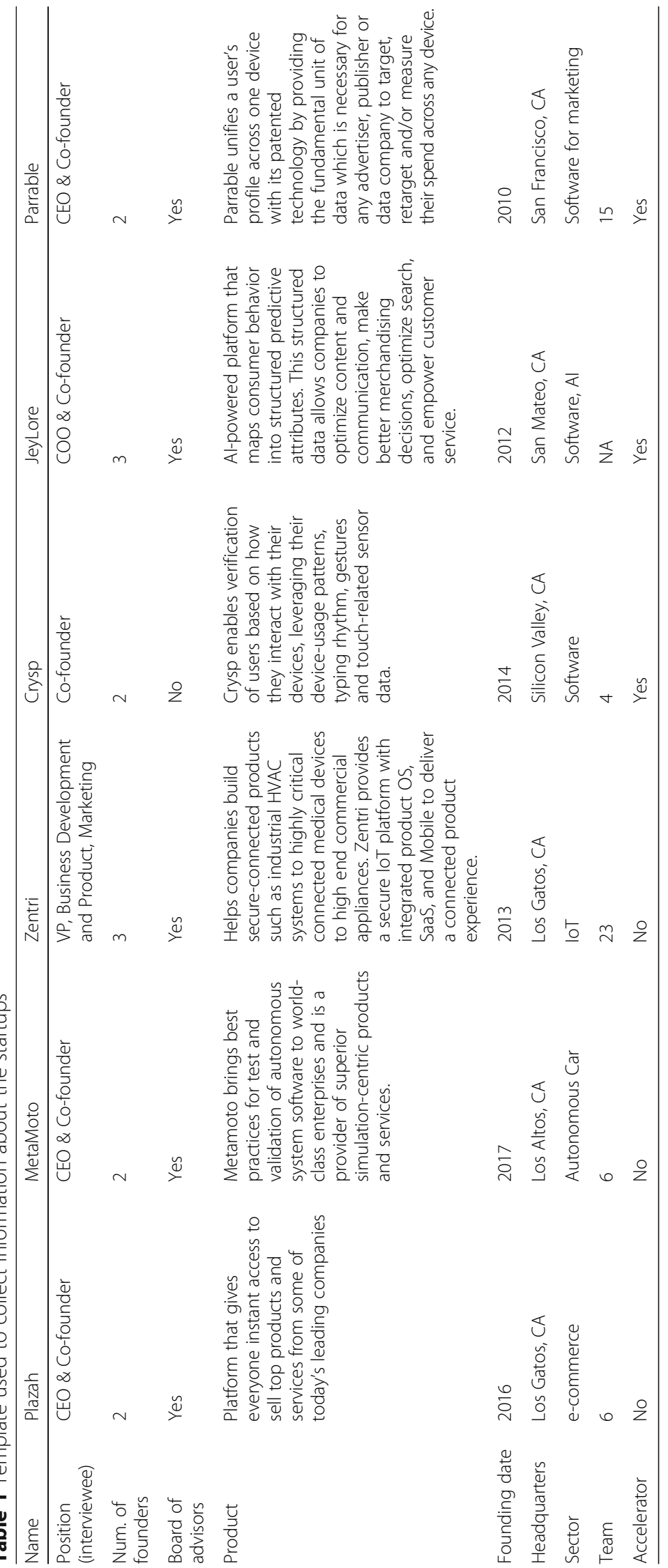




\begin{tabular}{|c|c|c|c|c|}
\hline \multicolumn{5}{|c|}{ General information } \\
\hline Name & & \multicolumn{2}{|c|}{ Founding date } & \\
\hline Position & & \multicolumn{2}{|c|}{ Headquarters } & \\
\hline Num. of founders & & \multicolumn{2}{|c|}{ Sector } & \\
\hline Nationalities & & \multicolumn{2}{|c|}{ Team } & \\
\hline Board of advisors & & \multicolumn{2}{|c|}{ Accelerator (yes/no) } & \\
\hline \multicolumn{5}{|l|}{ Product/Service } \\
\hline \multicolumn{5}{|c|}{ Stage of development and role of the TH agents } \\
\hline & Early & Launch & Growth & Maturity \\
\hline \multicolumn{5}{|l|}{ Government } \\
\hline \multicolumn{5}{|l|}{ University } \\
\hline Industry & & & & \\
\hline
\end{tabular}

Fig. 2 Template used to collect information about the startups

\section{Results}

This section is divided in two main parts. First, from the data collected (interviews and secondary sources) we summarize the main changes experienced by the agents of the Triple Helix model. Next, using the lifecycle of new venture creation, we map the role of the different agents at each stage of business development and indicate whether this role has changed compared to that in 2008 .

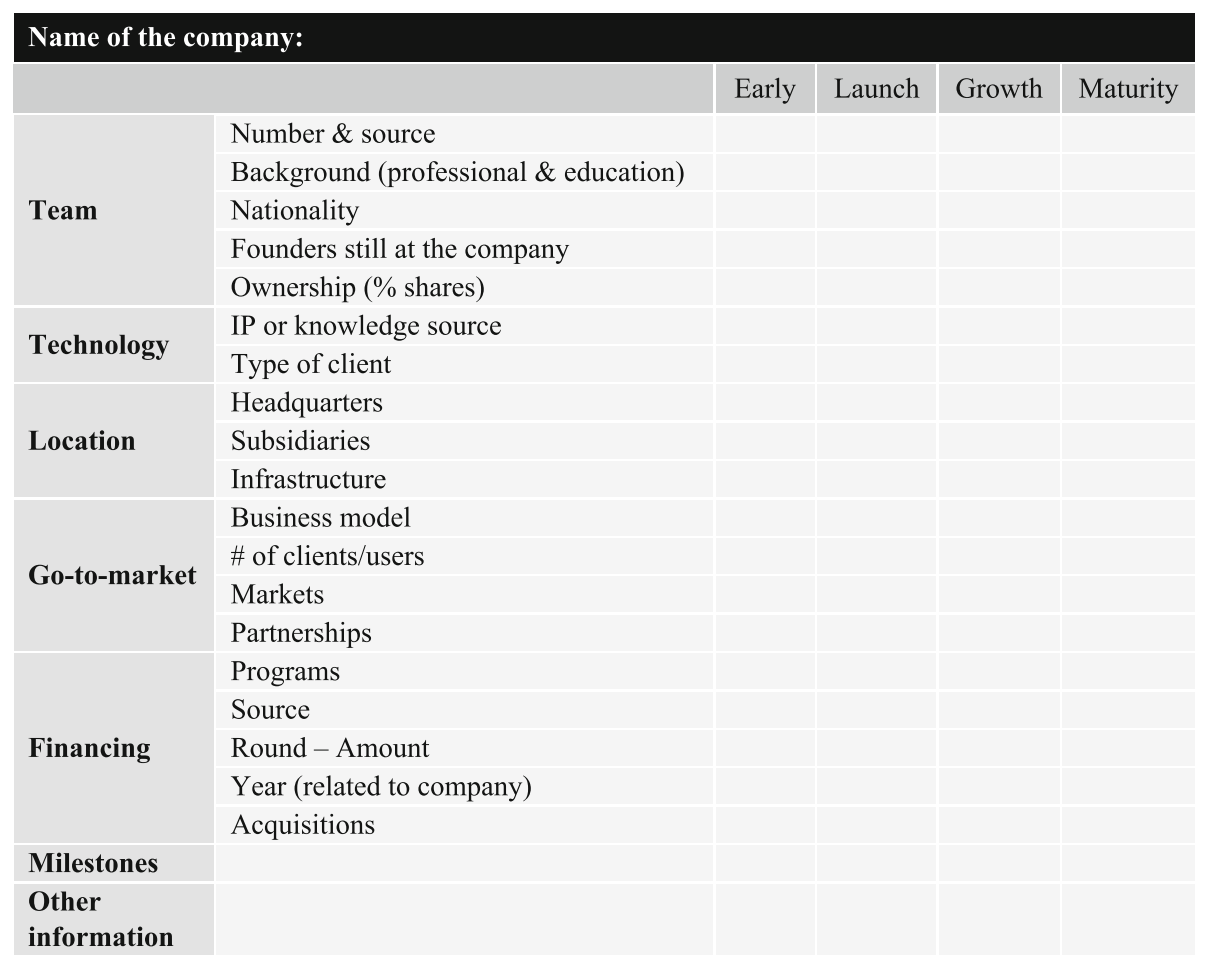

Fig. 3 Interview data template 
Table $\mathbf{2}$ List of interviews with experts

\begin{tabular}{lll}
\hline Triple Helix agent & Role & Company \\
\hline Industry & Business angel network & Keiretsu Forum \\
& Business angel & SandHill Angels, Silicon Catalyst \\
& Corporate investor & Samsung Catalyst Fund \\
& Corporate & IDEO, Dropbox, NIO \\
& Entrepreneur & Sensing Systems \\
& Entrepreneur & Promptu \\
University & University professor & University of California Berkeley \\
& University professor & Stanford University \\
Public administration & Local government & San Jose City Council \\
& State government & CITD \\
\hline
\end{tabular}

Evolution of the triple Helix agents

\section{Public administration}

Public administration in the U.S. has three levels: federal, State, and local, either at the county or the city level. Each administration plays a different role in the Triple Helix Model. Virtually all U.S. public R\&D funds are controlled by the Federal Government, with a few notable exceptions such as California's 2006 3-billion-dollar stem cell initiative (Etzkowitz and Rickne 2014). U.S. Government releases every year the total spending of the different agencies. As a general trend and since 2008, R\&D federal funds have mainly declined, however, have become more sophisticated. Nowadays, State Funds require consortium agreements, and universities can access to specific programs to promote commercialization of science.

Some agencies such as the Department of Homeland Security or the Environmental Protection Agency have seen the most drastic cuts, while the Department of Energy and the National Science Foundation (NSF) are the agencies exhibiting the major gains during this period. On the other hand, nuclear, efficiency, and renewable energy have all seen the greatest growth since 2008 .

The two main Federal funding programs for startups-SBIR and STTR-have remained stable. From 2008 to 2016, roughly 400 companies have been funded each year through these programs, issuing, up to date, 70,000 patents, closing 700 public companies, and approximately generating $\$ 41$ billion in venture capital investments. In 2013, the NSF launched the i-corps initiative to increase the impact of NSF funded research. This program aims at encouraging the commercialization of science and technology through partnerships between academia and industry. The Bay Area Node is focused on helping early-stage teams which have a fundamental technology, engineering or business model innovation. Through this initiative, teams learn how to define a scalable business model through the customer discovery process (Lean LaunchPad program). The State's direct support to its entrepreneurial ecosystem is through the iHub program launched by Governor Brown in 2013. However, the program ran out of money leaving consortiums without resources to achieve their original plan.

The State of California-a high-income tax state in comparison to Texas-employs tax exemptions as a way to keep companies within the State. During the last ten years manufacturing-specially related to biotechnology, physical, engineering, and life 
sciences-have been prioritized. Through modifications of the Federal R\&D tax exclusion, California is also securing high-skilled jobs.

At a local level, we have seen two different strategies. On the one hand, San Francisco has been highly competitive attracting new businesses into the city through incentive programs such as the Central Market Street \& Tenderloin Payroll Tax Exclusion. Although the program attracted new ventures into the city and allowed them to maintain their offices there, the economic effects remain to be seen when the actual incentives would finish by the end of 2018. If a high percentage of the attracted companies choose to keep their offices in the city, the project will be seen as a success. Yet, if most of them or the most famous ones decide to move out, only the negative effects-gentrification, rise of housing prices, and mobility problems-will remain and the project will be seen as a failure. Nevertheless, it has also been argued-as pointed out by J. Lang, former San Jose City Council chief economist-that the tax incentives were superfluous to underlying cultural trends and that firms would have located in any event and will continue to be attracted. On the other hand, San Jose has chosen to become a facilitator of technology on the streets, permitting emerging and consolidated companies to showcase or test their new technologies in a real environment. This also has allowed the city to reduce the cost of some expenses like lighting and Wi-Fi services. On May 2017, San Jose identified five corridors to be used by companies as a demonstration site for Autonomous Vehicles technology. Moreover, as Palo Alto, Menlo Park, Mountain View and Cupertino, the inner core of Silicon Valley have filled up, at least in their traditional suburban guise, San Jose still has the potential for aggregation of large parcels of land, favored by the likes of Google and Apple for their projected expansion.

The overarching conclusion is that while the presence of $\mathrm{NIH}$, defense department and CIA persists, government's role as investor is steadily shrinking in Silicon Valley in comparison to the rise of private investment, locally and globally. Both startups (SBIR/ STTR Funds) and universities (R\&D Programs) are relying on private funds to develop their new technologies. During this last decade we have also witnessed a shift in the cities' role, moving from customers to facilitators. Cities like San Jose are becoming technology platforms, allowing emerging and consolidated companies to showcase their new technologies in a real environment. This new paradigm requires new strategies and ways of operating, both for companies and for public administration organizations.

\section{Industry}

According to J.S. Engel, director of the Entrepreneurship Program at the Haas School of Business (University of California, Berkeley), the main changes seen in the industry refer to the rise of accelerator programs and the role that big tech corporations are acquiring in Silicon Valley. While in 2007 there were only 2 accelerator programs in the U.S., by 2014 the number raised exponentially up to 170 . The leading accelerator programs include funding, which, combined with training and access to powerful networks, suggest a positive impact on the startups but their overall impact remains to be assessed. Following J. Iglehart, one of the experts that were interviewed and president of the international division at Keiretsu Forum "incubators and accelerators help entrepreneurs to present a better business case to investors". A clear benefit of these programs is the big increase of seed deals sealed. Traditional Tech Corporations have been 
involved with startups. However, big tech companies that were startups 10-15 years ago are now changing the "rules" by engaging sooner with startups.

As pointed out in the interview with C. Chu, the managing director at Samsung Catalyst Fund, Corporate Venture Capital funds (CVCs), Corporate Accelerators and acquisitions are the most popular ways of engagement, but also becoming early costumers, organizing hackathons or engaging in partnerships. Despite the long time existence of CVCs, the present amount of funds is extraordinary. This growth is caused, in part, by traditionally non-tech buyers entering the market seeking for innovation and technology such as Walmart, L'Oreal, Unilever, 7-Eleven, Campbell Soups or General Mills, which all have now their own CVC program. However, the immaturity of some of these CVCs is causing a high level of skepticism of some entrepreneurs and investors. As they keep their presence in the market, speak up their intentions and start leading some rounds, their role will probably consolidate as mature agents of the ecosystem.

Similarly, C. Chu stressed that corporations are following the trend of accelerators by creating their own programs. While models continue to evolve-most organizations are still experimenting with different ways of setting up and managing their accelerator initiatives-we will have to wait to see the real benefits of these initiatives. This observation is in accordance with that of J. Iglehart, who states that as more accelerator programs appear, and angel investors are more organized and reachable sources of investment for seed and early stages have also increased rapidly. Some corporates are also participating at these stages to keep track on early development technologies. Using C. Chu's words, "CVCs are leading the rounds now".

While the number of seed and early stage deals is increasing-which is encouraging for new startups-the investment funnel in later stages is shrinking. As stated by J.S. Engel in the interview, we now see fewer deals but bigger share of the investment at expansion and later stages, therefore, fewer companies are being funded with large amounts of money. We are also seeing less IPOs in the Silicon Valley. High valuations of some Silicon Valley Tech companies including Uber, Dropbox or Zenefits are challenging their odds of a successful IPO, while their investors cannot cash out or even increase their investments. VC firms are also getting bigger with offices all around the U.S. Interestingly, those that did not have their headquarters in Silicon Valley back in 2008 they now do have them there. The number of deals made in 2016 by the most active firms is almost twice those in 2008, and more surprisingly two accelerators and some angel groups are on the top 15 in number of deals. As for the thematic areas of investment, the hottest ones in the U.S. in 2017 were artificial intelligence, cybersecurity and auto tech, but all of them saw a drop in invested dollars during the last quarter of the 2016.

\section{Universities}

Universities are still an important place where entrepreneurs meet and decide to start a business. For long time, universities were not taking full advantage of this role, losing an opportunity to increase their contribution to regional development and their own revenue. During the last decade, however, we have seen universities taking new roles and embracing their entrepreneurs by actively promoting entrepreneurship, strengthening their ties with VCs and investors, acting as investors, and actively promoting the commercialization of science. The University of California, Berkeley and UCSF have become significant 
entrepreneurs, not only supplying faculty generated IP, but also incubator programs, like QB3 that go beyond Stanford's commitment. In this respect, and according to J.S. Engel "universities are shifting from licensing models to venture models".

As young companies have been responsible for a majority of net job growth over the last couple decades, entrepreneurship has increasingly become a fundamental force at universities nationwide. To attract the best aspiring entrepreneurs, many universities started thinking outside the box and expanded their offerings to support students across various programs. Universities are fostering entrepreneur-friendly environments through a combination of different strategies. First, they are going beyond business students, that is, some schools are integrating entrepreneurship courses as a core part in the curricula of many disciplines, including engineering, medicine and journalism. Second, universities are increasingly teaming up with the industry to allow students to gain experience by working at startups or venture capitalist firms. Third, as fundraising is one of the more difficult jobs as an entrepreneur, some universities are helping their students to master it through real practice. Fourth, in order to succeed in a business, people from different backgrounds and skills are needed; therefore, universities are creating multidisciplinary programs were students from engineering, medicine, law or business work together in a project. Other strategies to help students to pursue an entrepreneurial path and, at the same time, strengthen ties between university and future entrepreneurs include (1) Business/Lean Plan competitions or awards; (2) cross-faculty programs; (3) providing infrastructure through incubators and accelerators; and (4) promoting commercialization of science (e.g., i-corps).

Offices of Technology License (OTL) are also becoming more 'startup-friendly'. While in 2008 OTLs rarely considered the creation of university related spin-off or technology transfer to a startup as a key indicator, as of today, universities in the Silicon Valley include both metrics as performance indicators in their annual reports. Even further, some universities have developed specific programs to help their researchers or professors to pursue a business based on an OTL technology.

Through the prolific rise of university-backed VC Funds, universities are also getting closer to investors and VC firms. A clear example is the \$250Million Fund from the University of California. Investing in the ventures of their own students, researchers or professors, universities are demanding their share in the seed/early round space. This entails an increased need to establish formal connections and relations with other investors to help their companies secure in the next rounds. To this end, universities and VC firms are creating their own collaboration spaces. The Student Programs that some VCs run each year are just an example. Investors and VC firms also participate as a supervisors or advisors in affiliated VC Funds or Student Venture Funds. Similarly, law firms are also partnering with university-related incubators or accelerators to provide free guidance to young companies, either directly or through the University's Law Faculty and students.

\section{Other relevant factors}

The addition of San Francisco to Silicon Valley, initially limited to Santa Clara County, but since extended to the East Bay and even into the Central Valley as "Greater Silicon Valley" has changed the demographics of the area. The inclusion of city was not induced only by the incentives given by the city in 2008. Silicon Valley's younger 
generations-following the millennial demand of living in a "walkable city" (Florida 2002) - were forced to move to the closest, San Francisco, even if they had to do up to four hours commute per day.

San Francisco embraced this young population, and helped to create an environment to attract tech companies. The redevelopment of SOMA and Potrero Hills, and the widely criticized Payroll Tax Exclusions are some of the examples that have driven the city to lead job creation in Silicon Valley during the last 10 years. This has caused the known bad-effects of gentrification (Atkinson 2004) and the creation of a new economy in the inner city (Hutton 2000, 2004).

The exponential growth of the main tech companies' workforce is a challenge for the area. While these companies are growing around Mountain View, Cupertino, Menlo Park and Santa Clara by building their own "private cities", the real cities and counties cannot grow at same pace and provide the necessary infrastructure. Low housing availability and skyrocketing rent prices are coercing non-tech employees to move further away or submit and pay unreasonable and highly unstable rents.

San Francisco and Silicon Valley have developed a synergy. Singles and couples with no children tend to live in the city. Once families grow, they move out of the city to quieter and family-friendly areas like Palo Alto, Los Gatos or Mountain View. A similar phenomenon occurs to companies. Startups begin their journey in the city, where companies take advantage of social agglomeration factors such as critical masses of skills and relationships, access to information, and the availability of specific infrastructure (Utterback and Afuah 1998; Hutton 2004; Porter 1995). Once their venture reaches a certain level-typically, after early stage-they are forced to leave the city to grow on a cheaper and distraction-free environment. The increase of movements between cities, neighborhoods and corporate-cities are collapsing the infrastructure, which is becoming a real problem in the area. It is important to notice that Bay Area was for decades a low densely populated area and its infrastructure is rather outdated. As O'Mara (2011) pointed out, "Silicon Valley may be a unique ecosystem for technology creation, but it falls short on many fronts in terms of functioning well as an urban place. It is haphazardly planned and economically polarized. It is crowded and car-dependent to a degree that lowers its quality of life and degrades the natural beauty that lured people there in the first place."

Listening to their employees' demands and usually against their corporate philosophy, some companies recently started opening small offices in San Francisco, or redesigning their campuses to look less like industrial parks and more like main streets of very hip and cosmopolitan small towns. Being in a cool neighborhood, helps with recruitment and retention.

All this job growth has come with an increase in base salary of high-skilled professionals, not only in per capita personal income but also in disparity across Silicon Valley. Precisely, the increase of personal income is also becoming one the main problems for new ventures, which struggle to recruit their first employees. On the contrary, Silicon Valley's population is growing less rapidly in recent years, primarily due to the large increase in net domestic out-migration. The region's birth rates remain relatively low, and the population has aged significantly over the past decade.

\section{Mapping the evolution}

To facilitate the interpretation of the results, we distinguish among three levels of change: (1) no-change, that is, when the agent is keeping the same role or experiences 
minor (but non-substantial) changes in the performance or development; (2) incremental change, when the agent is performing the same role but with a different approach or perspective; and (3) disruptive change, which entails the appearance of a new agent, a new role or a new task is developed by an agent not usually involved before. By adopting this approach, it is possible to graphically illustrate (Fig. 4) the not only the relative importance of each of the Triple Helix agents in supporting the development of technology ventures in Silicon Valley-given by the size of the spheres)-but also the magnitude of the changes during the past 10 years.

As it is shown, the importance of the Triple Helix agents in supporting business development varies from one stage to another, and what is more, their role has evolved during this 10 -years period. Specifically, universities keep their important role during the inception stage of companies. A new industry agent raised at this stage, namely, accelerators. Business angels are also increasing the role of industry at this early stage. Government is trying to get closer to both universities and industry enlarging the collaboration area. At the launching phase, few changes are observed in the relative importance of each agent. Universities and industry are strengthening their ties, while government adopts a secondary role. Next, as companies grow, their necessities change and regulations start to affect them. Thus, during the growing stage, public administration has a slightly bigger influence, allowing companies to showcase their solutions in cities and through policy regulations. On the contrary, at this stage, universities seem to lose part of their influence but less than they did 10 years ago, as they can keep their ties with their startups for a longer period through their VC funds. Finally, during maturity, industry remains the most important agent at this stage. Administration keeps its role as a regulator while universities continue to supply human capital and new ideas although some think their relevance has declined with firm growth and the revival of corporate research labs. Less interaction between the three agents is identified compared to 10 years ago. To sum up, as an innovative ecosystem evolves, so does the role played by the Triple Helix agents.

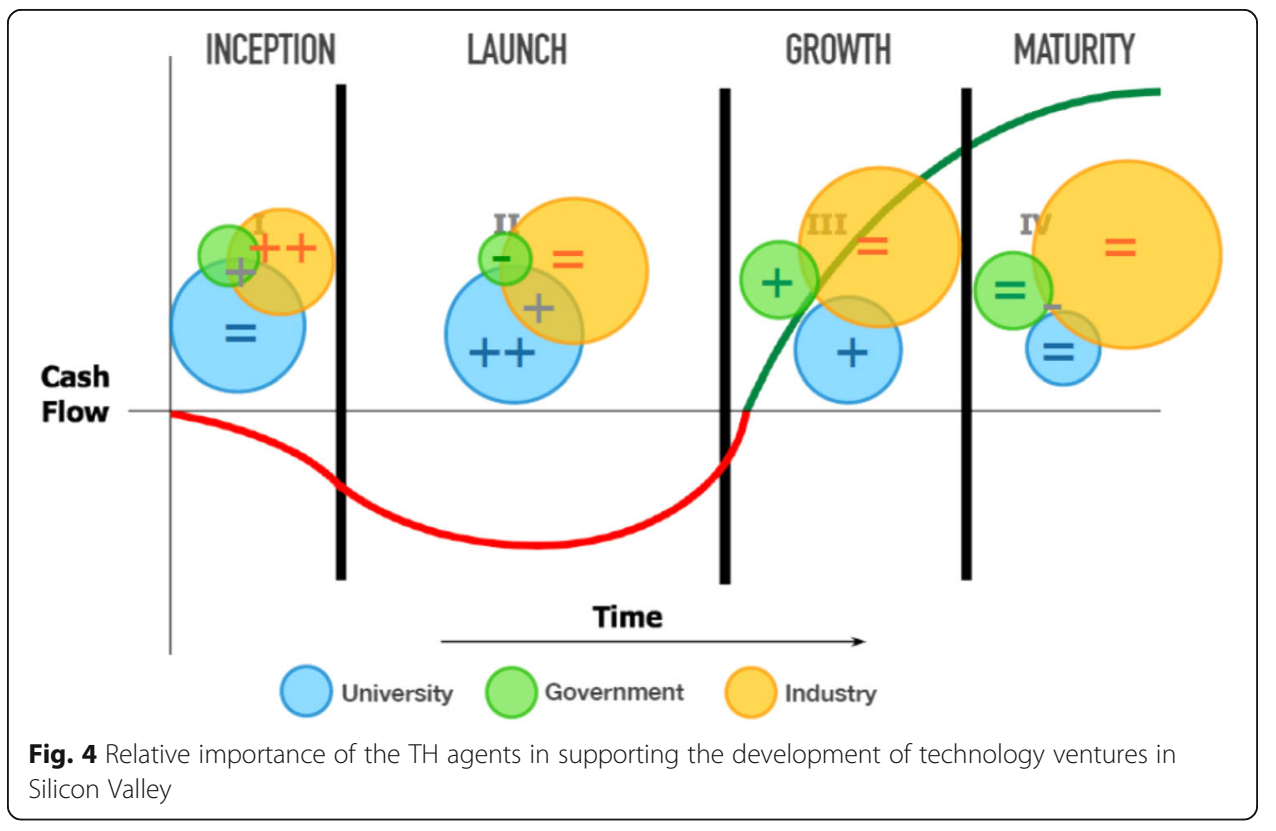




\section{Discussion and conclusions}

In this study we have analyzed the evolution of Silicon Valley innovation ecosystem, paying special attention to the role played by the agents of the Triple Helix model in startup formation. Based on the data collected and by comparing the current situation to the one described in del-Palacio (2009), we have also been able to disentangle the main changes that have occurred during the last decade and discussed the potential triggers and implications behind this evolution. This way, we have been able to answer our two initial research questions.

The rise of acceleration programs is one of the main changes observed during this 10 -year period. While in 2007 there were just 2 accelerator programs in the U.S., by 2014 the number was 170, with more than 20 located in Silicon Valley. Leading accelerator programs include funding, which combined with training and access to powerful networks, results in high rates of startup formation and a notable increase of seed deals sealed. Yet, their overall net impact still remains an issue, and future studies should be addressed in order to shed new light.

Other changes include the way big corporations interact with startups. New big tech companies-those that were startups 10-15 years ago-are changing the "rules", engaging sooner with startups. Corporate Venture Capital funds (CVCs), Corporate Accelerators and acquisitions are the most popular ways of engagement. Despite the long time existence of CVCs, the current amount of funds is extraordinary, including traditionally non-tech companies such as 7-Eleven or Walmart. Regardless the high performance of some of them-such as Intel or Google Ventures-the immaturity of others is causing a high level of skepticism from some entrepreneurs and investors. Nevertheless, it is expected that CVCs will consolidate as mature agents of the ecosystem in the near future. Accelerator programs are another mechanism corporations use to engage with startups. Yet, since most organizations are still experimenting with different ways of setting up and managing their accelerator initiatives-either running the program in-house or outsourcing its administration to a partner such as Techstars, LMarks, or Nest-we should still have to wait a couple of years to see the real effects of such initiatives.

Another key finding is the shift in investment stages. Business Angels are becoming more organized and syndicated which is helping to spread their work and professionalize their role. The larger the number of accelerator programs appear, the more organized and reachable angel investors become. This, in turn, has occurred at the expenses of incubators. Startups have now easier access to technical and marketing (digital) resources, such as cloud or Adwords. Technological infrastructures are also cheaper. Taken as a whole, this implies that for an entrepreneur it is much cheaper and easier to start an entrepreneurial endeavor today than 10 years ago. But, while the number of seed and early stage deals is increasing, the investment funnel in later stages is shrinking, turning growth stage as the most difficult for startups. Growth has thus become the toughest stage. Companies have more competition-more companies are funded in seed and early stages-hiring is more expensive, and investment is concentrated in fewer companies at this stage. Indeed, VCs are mainly concentrating their investments in later stages, with larger investments in fewer companies, playing "too big to fail".

Universities, and especially their professors, have become a source of knowledge for investors that want to keep track on what is disruptive and feasible technologically speaking. Consequently, financial and corporate investors are approaching university 
labs or technology transfer units looking for high-tech startups. Also, universities are also getting closer to industry, offering a wide variety of programs and initiatives aimed at helping students pursue an entrepreneurial path.

While the Science Park was invented at Stanford in the 1950's; on a large tract of land adjacent to campus, it was not spacious enough to meet the request to host a super-firm like Facebook. On the other hand, Hewlett-Packard, the leading firm during its founding era, is departing as it no longer requires such a large space, with much of its engineering work now carried out at lower cost in India. From the interview with T. Griego, managing director and asset manager at Stanford Research Park it can be concluded the Park's management sees a need to evolve along the lines of Stockholm's Kista, building multi-story housing to meet the university's needs but is stymied by local opposition to density, expressed through Palo Alto's control of university development plans. Thus, the Science Park is basically irrelevant to addressing contemporary Silicon Valley needs. Nevertheless, it continues to play a useful role supplying income to the university and hosting StartX, the university's student initiated accelerator, close enough for easy access but just outside the bounds of the university's intellectual property regime (Etzkowitz 2013b).

The evidences gathered suggest that the profile of the entrepreneur has also changed. They are now younger and with more technical skills. Entrepreneurs start their businesses everywhere but tend to move to Silicon Valley to grow. To do so, they tend to build strong ties with experts via the formalization of Advisory Boards.

Talent-main driver of Silicon Valley's growth and success-is also becoming a challenge, especially for new startups that struggle to recruit their first employees. The recent collapse of the H1B Visa Program—defined to attract international talent-and the exponential growth of the main tech companies' workforce has caused a shortage of engineers that have seen an increase of base salary over the average. New startups, as well as older and larger firms, are inclined to move their engineering teams partially abroad. Other entrepreneurs are following a different path, starting their companies elsewhere and moving to Silicon Valley to grow. Both models seem to replicate the Israeli model, followed also by many international companies when entering in Silicon Valley. According to the interview with A. Castellarnau, VP of user experience at NIO and former Dropbox and IDEO employee, these models might lead to a change in the type of companies based in Silicon Valley in the near future, when fewer engineers will be needed, and only the core of the company-founders, business development and design team-will be in Silicon Valley. At this point is also worth considering the housing regulations around San Francisco and Silicon Valley, which are not allowing enough construction to keep up with demand. This has raised the price of housing beyond a reasonable level, creating more separation between high-tech workers and the rest of the population.

Through the changes identified in this study, we can conclude that the role of triple helix agents has evolved over time in Silicon Valley. Silicon Valley is an industry led triple helix in its mature phase of development, an even stronger conclusion in comparison to a decade ago. Even though this study helps to identify and characterize the evolution of Innovative Ecosystems, additional analysis is needed to further clarify the stages of development and their characteristics (Etzkowitz and Klofsten 2005; Etzkowitz and Dzisah 2008). Finally, similar studies in weak and emerging entrepreneurial ecosystems are worth to be conducted, since different and novel behaviors are expected to be observed in less advanced innovative ecosystems, following the differentiation of Silicon Valley from Route 128. 
Since the Triple Helix Model is used to characterize an Innovative Ecosystem, we can extrapolate that the Innovative Ecosystem also evolves over time. Notwithstanding, we cannot conclude if the changes are driven by the evolution of one of the agents or if each one of them has independently evolved by its own. The information collected through interviews and qualitative report does not definitively show any specific event that triggered changes in the rest. Nevertheless, the emergence of "supercorps" like Face book, Apple and Google are reshaping the start-up dynamic into a "try-out" model, with likelihood of being purchased (Martinez 2017). Even high growth firms like Spotify and Arm that might have remained independent previously are less likely to resist an egregious offer. Concentration may slow innovation, displacing the original factor of diversity and interaction among relative equals that distinguished Silicon Valley as a highly distinctive industrial district, to date.

\section{Additional file}

Additional file 1: Translation of the abstract into Arabic. (PDF $40 \mathrm{~kb}$ )

\section{Abbreviations}

CVC: Corporate Venture Capital; IPO: Initial Public Offering; M\&A: Merger and acquisition; NSF: National Science Foundation; OTL: Offices of Technology License; SBIR: Small Business Innovation Research; STTR: Small Business Technology Transfer; UCSF: University of California, San Francisco; VC: Venture Capital

\section{Acknowledgements}

The authors would like to thank Monica Botey for her help with the interviews. Likewise, the authors are really grateful to all interviewees that generously accepted to participate in this study.

Funding

No sources of funding to be declared.

Availability of data and materials

Not applicable.

Authors' contributions

All authors have equally contributed to this work. All authors read and approved the final manuscript

\section{Competing interests}

The authors declare that they have no competing interests.

\section{Publisher's Note}

Springer Nature remains neutral with regard to jurisdictional claims in published maps and institutional affiliations.

\section{Author details}

${ }^{1}$ Innova Institute \& Technova Barcelona, La Salle - Ramon Llull University, Sant Joan de La Salle, 42, 08022 Barcelona, Spain. '2Department of Economy and Business Organization, Universitat Internacional de Catalunya, C. Immaculada, 22, 08017 Barcelona, Spain. ${ }^{3}$ International Triple Helix Institute (ITHI), 1470 Sand Hill Road, Palo Alto, CA 94304, USA.

${ }^{4}$ Center for Innovation Management Research (CIMR), Birkbeck, London University, London, UK.

Received: 31 August 2018 Accepted: 12 November 2018

Published online: 05 December 2018

\section{References}

Atkinson R (2004) The evidence on the impact of gentrification: new lessons for the urban renaissance? Int J of Housing Pol $4(1): 107-131$

Bresnahan T, Gambardella A, Saxenian A (2001) 'Old economy' inputs for 'new economy' outcomes: cluster formation in the new silicon valleys. Ind Corp Change 10(4):835-860

Carayannis EG, Grigoroudis E, Campbell DF, Meissner D, Stamati D (2018) The ecosystem as helix: an exploratory theorybuilding study of regional co-opetitive entrepreneurial ecosystems as quadruple/quintuple Helix innovation models. R\&D Manage 48(1):148-162

Carreyrou J (2018) Bad blood: secrets and lies in a Silicon Valley startup. Picador, New York

Chen F, Wu C, Yang W (2016) A new approach for the cooperation between academia and industry: an empirical analysis of the triple helix in East China. Sci Technol Soc 21(2):181-204

Chen SH, Lin WT (2017) The dynamic role of universities in developing an emerging sector: a case study of the biotechnology sector. Technol Forecast Soc 123:283-297

Cheyre C, Kowalski J, Veloso FM (2015) Spinoffs and the Ascension of Silicon Valley. Ind Corp Change 24(4):837-858 
Daniels CU, Ustyuzhantseva O, Yao W (2017) Innovation for inclusive development, public policy support and triple helix: perspectives from BRICS. Afr J Sci Technol Inno Dev 9(5):513-527

Deakin M, Leydesdorff L (2014) The triple helix model of smart cities: A neo-evolutionary perspective. In: Deakin M (ed) Smart cities: Governing, modelling and analysing the transition. Routledge, Oxfordshire

del-Palacio I (2009) The capital gap for small technology companies in Spain: Public venture capital to the rescue? Doctoral dissertation. Universitat Politècnica de Catalunya, Barcelona

Engel JS (2015) Global clusters of innovation: lessons from Silicon Valley. Calif Manag Rev 57(2):36-65

Etzkowitz H (2013a) Silicon Valley at risk: the sustainability of an innovative region. Soc Sc Inform 52(4):513-538

Etzkowitz H (2013b) StartX and the paradox of success: filling the gap in Stanford University's entrepreneurial development. Soc Sc Inform 52(4):605-627

Etzkowitz H, Dzisah J (2008) Unity and Diversity in high-tech growth and renewal: learning from Boston and Silicon Valley. Eur Plan Stud 16(8):1009-1024

Etzkowitz H, Klofsten M (2005) The innovating region: toward a theory of knowledge-based regional development. R\&D Manage 35(3):243-255

Etzkowitz H, Leydesdorff L (2000) The dynamics of innovation: from National Systems and "mode 2" to a triple Helix of university-industry-government relations. Res Policy 29(2):109-123

Etzkowitz H, Rickne A (2014) Citizen-driven innovation: stem cell scientists, patient advocates and financial innovators in the making of the California Institute of Regenerative Medicine (CIRM). Prometheus 32(4):369-384

Etzkowitz H, Zhou C (2007) Regional innovation initiator: the entrepreneurial university in various triple helix models. In: Conference theme paper presented at the 6th International Triple Helix Conference on University, Industry and Government Linkages. National University of Singapore, Singapore 16-18 May 2007

Etzkowitz H, Zhou C (2018) The triple Helix: university-industry-government innovation and entrepreneurship, 2nd edn. Routledge, London

Ferrary M, Granovetter M (2009) The role of venture capital firms in Silicon Valley's complex innovation network. Econ Soc 38(2):326-359

Florida R (2002) The rise of the creative class: and how it's transforming work, leisure, community and every day life. Basic. New York

Fogelberg H, Thorpenberg S (2012) Regional innovation policy and public-private partnership: the case of triple Helix arenas in Western Sweden. Sci Public Policy 39(3):347-356

Freeman J, Engel JS (2007) Models of innovation: startups and mature corporations. Calif Manag Rev 50(1):94-119

Geoghegan W, O'Kane C, Fitzgerald C (2015) Technology transfer offices as a nexus within the triple helix: the progression of the university's role. Int J Technol Manag 68(3-4):255-277

Guerrero M, Urbano D (2017) The impact of triple Helix agents on entrepreneurial innovations' performance: an inside look at enterprises located in an emerging economy. Technol Forecast Soc 119:294-309

Hutton TA (2000) Reconstructed production landscapes in the postmodern city: applied design and creative services in the metropolitan core. Urban Geogr 21(4):285-317

Hutton TA (2004) The new economy of the inner city. Cities 21(2):89-108

Jauhiainen JS, Suorsa K (2008) Triple Helix in the periphery: the case of multipolis in northern Finland. Camb J Reg Econ Soc 1(2):285-301

Jensen C, Tragardh B (2004) Narrating the triple Helix concept in "weak" regions: lessons from Sweden. Int J Techno Manage 27(5):513-530

Johnson WH (2008) Roles, resources and benefits of intermediate organizations supporting triple helix collaborative R\&D: the case of Precarn. Technovation 28(8):495-505

Katz BM (2015) Make it new: a history of Silicon Valley design. MIT Press, Boston

Kim Y, Kim W, Yang T (2012) The effect of the triple helix system and habitat on regional entrepreneurship: empirical evidence from the US. Res Policy 41(1):154-166

Leydesdorff L, Etzkowitz H (1996) Emergence of a triple Helix of university_industry_government relations. Sci Public Policy 23(5):279-286

Leydesdorff L, Fritsch M (2006) Measuring the knowledge base of regional innovation systems in Germany in terms of a triple Helix dynamics. Res Policy 35(10):1538-1553

Martin R, Sunley P, Gardiner B, Evenhuis E, Tyler P (2018) The city dimension of the productivity growth puzzle: the relative role of structural change and within-sector slowdown. J Econ Geogr 18(3):539-570

Martinez A (2017) Chaos monkeys: obscene fortune and random failure in Silicon Valley. HarperCollins, New York

O'Mara M (2011) Silicon Valleys. Boom: A Journal of California 1(2):75-81

Ooms W, Werker C, Caniëls MC, Van Den Bosch H (2015) Research orientation and agglomeration: can every region become a Silicon Valley? Technovation 45:78-92

Porter ME (1995) The competitive advantage of the inner city. Harvard Bus Rev 73(3):55-71

Pugh R (2017) Universities and economic development in lagging regions: 'triple Helix' policy in Wales. Reg Stud 51(7):982-993

Ranga LM, Miedema J, Jorna R (2008) Enhancing the innovative capacity of small firms through triple helix interactions: challenges and opportunities. Technol Anal Strateg Journal 20(6):697-716

Rodrigues C, Melo Al (2013) The triple Helix model as inspiration for local development policies: an experience-based perspective. Int J Urban Regional 37(5):1675-1687

Saad M, Zawdie G (2005) From technology transfer to the emergence of a triple helix culture: the experience of Algeria in innovation and technological capability development. Technol Anal Strateg Journal 17(1):89-103

Samuels WJ (1998) The founding of institutional economics: the leisure class and sovereignty. Routledge, London

Saxenian A (1985) The genesis of Silicon Valley. In: Hall P, Markusen A (eds) Silicon landscapes. Allen \& Unwin, London

Smith HL, Bagchi-Sen S (2010) Triple helix and regional development: a perspective from Oxfordshire in the UK. Technol Anal Strateg Journal 22(7):805-818

Utterback JM, Afuah AN (1998) The dynamic 'diamond': a technological innovation perspective. Econ Innov New Technol 6(2-3):183-200

Yin RK (1984) Case study research: design and methods. Sage Publications, Beverly Hills, CA 